\title{
REFLECTION OF PROMOTIONAL STRATEGY IN THE DIVERSITY OF NATIONAL PAVILIONS DURING EXPO 2015
}

This paper aims to classify pavilions prepared for universal expositions. For the purpose of the classification, cohesion between displays and assumptions of national branding, as well as the central idea of Expo was taken into consideration. The first part of the article presents the key areas and determinants of managing a performance project during a world exposition. The second part of the publication contains an assessment and classification of national pavilions, which were based on the observation conducted by the author during Expo 2015. In the context of nation branding indicated: pavilions which fit squarely into a current promotional strategy; pavilions which are not connected with a current concept of promotion, however, which consider existing social, economic or political factors; pavilions which are not in line with a long-term concept of country promotion and do not take into account present social, economic or political factors. Moreover, taking into consideration the level of adjustment of particular countries' performances to a theme of Expo, pavilions were be categorised as: pavilions which correspond closely with the exhibition theme; pavilions which correspond loosely with the exhibition theme; pavilions which do not correspond at all with the exhibition theme. The exposures of Ethiopia, France, Germany, Slovakia, Slovenia and Turkmenistan are given as examples. Special attention was given to the Polish pavilion. Finally, the author focused on whether participation in world exhibitions in the 21 st century is legitimate - taking into account the context of costs related to the preparation of pavilions and universal access to the Internet.

Keywords: Expo exhibitions, trade fair performance management, exhibition architecture, country image.

\section{INTRODUCTION}

Great universal expositions, whose aim is to promote achievements of the whole civilisation and inform about successes of individual countries, have been held for more than one and a half century. Nowadays, almost 200 exhibitors every five years strive to display their offers in an appealing manner and thus attract the attention of tourists, investors and media representatives. Preparing and staging a six-month long display requires the effort of many people who have to get involved in such an undertaking for at least one year, and moreover, necessitates huge financial outlays. Therefore, a proper approach to exhibition project management is of crucial importance.

This article aims to put forward a classification of pavilions erected for Expo events, considering whether they conform to the assumptions of national branding and adhere to the central concept of an exhibition. Performances given by individual countries were

\footnotetext{
${ }^{1}$ Marcin Gębarowski, PhD, Department of Marketing, Faculty of Management, Rzeszów University of Technology, Powstańców Warszawy 8, 35-959 Rzeszów , tel.: + 48 (17) 865 14 74, e-mail: marcing@ prz.edu.pl.
} 
assessed based on the two-day long observation conducted during the world exposition which was held in Milan in 2015.

\section{PROCESS OF PREPARING NATIONAL PAVILION - MANAGERIAL AP- PROACH}

Currently, the largest exhibition events - Expos - are referred to as world (universal) expositions. Apart from them, also International (specialised) Expositions with narrower themes, which are smaller in scale, are organised. Rights to host both the types of exhibitions are granted to selected cities by BIE - Bureau International des Expositions (The International Exhibitions Bureau), which is an association of 168 countries.

It is believed that the event which started the history of world expositions was the Great Exhibition of the Works of Industry of All Nations. The exhibition was held at London's Hyde Park in 1851. After that event, different countries hosted exhibitions devoted to the review of worldwide achievements - in the dimension of both the whole civilisation and individual states, and those exhibitions were staged every couple of years, at irregular intervals. Since 2000, the expositions have been taking place every five years. The last edition was organised in 2015 in Milan, and the next Expo opens in 2020 in Dubai. In the period of more than one and a half century, nearly 70 exhibitions, different from each other both in terms of their importance and nature, have been staged, including 34 events that enjoyed the status of universal expositions.

Contemporary world expositions are attended by approx. 200 exhibitors (countries, international organisations and so-called Expo partners). Therefore, there is strong competition for visitors' attention. An average person who arrives to see a fair, even when staying for the whole week on the premises of the exposition, is not able to visit all the displays. That is why most exhibitors compete with each other using their own pavilions, which are usually original structures, as well as stage their performances following action-packed programmes comprising multiple interesting events.

It should be stated, based on a review of books and articles, that scientific literature comprises very few publications on world expositions. Authors of the works published thus far sometimes focused on marketing aspects of Expo events. Only few articles analysed the dimensionality of the image of the very events ${ }^{2}$, their impact on the image of a host city ${ }^{3}$ and a host country ${ }^{4}$. In the context of marketing, some authors turned their attention to the motives for participating in exhibitions ${ }^{5}$, as well as to experiences that visitors

\footnotetext{
${ }^{2}$ C.Q. Deng, M. Li, H. Shen, Developing a measurement scale for event image, "Journal of Hospitality \& Tourism Research", 2015/39(2), pp. 245-270.

${ }^{3}$ M. De Carlo, S. Canali, A. Pritchard, N. Morgan, Moving Milan towards Expo 2015: designing culture into a city brand, "Journal of Place Management and Development", 2009/2(1), pp. 8-22; L. Yu, Ch. Wang, J. Seo, Mega event and destination brand: 2010 Shanghai Expo, "International Journal of Event and Festival Management”, 2012/3(1), pp. 46-65; K. Xue, X. Chen, M. Yu, Can the World Expo change a city's image through foreign media reports?, "Public Relations Review", 2012/38(5), pp. 746-754; C.Q. Deng, M. Li, A model of event-destination image transfer, "Journal of Travel Research", 2014/53(1), pp. 69-82.

${ }^{4}$ N. Chen, Branding national images: The 2008 Beijing Summer Olympics, 2010 Shanghai World Expo, and 2010 Guangzhou Asian Games, "Public Relations Review”, 2012/38(5), pp. 731-745.

${ }^{5}$ Ch.-K. Lee, S.K. Kang, Y.-K. Lee, Segmentation of Mega Event Motivation: The Case of Expo 2010 Shanghai China, “Asia Pacific Journal of Tourism Research", 2013/18(6), pp. 637-660.
} 
have $^{6}$. However, there is a lack of publications addressing a management aspect of the preparation of national performances at Expos.

Preparing a display which will attract a big audience requires proper exhibition project management. Such management entails taking decisions on many planes (Fig. 1). The first decision-related area is represented by a strategic (conceptual) plane and involves mainly developing a concept of a performance. Such a concept should correspond well with the central theme of Expo, as well as allow for creating a unique pavilion and taking actions aimed at making a specific country's display distinguishable from those made by other countries. Furthermore, the performance concept should be cohesive with other marketing activities performed as a part of the philosophy developed to create an image of a specific country. Both what the pavilion looks like and what is happening during the performance should result from a national branding strategy, strengthening thus a concept of country positioning that is being implemented consistently. Conceptual activities are influenced also by current political (especially in states with the totalitarian system) and economic factors (e.g. willingness to support the export of resources or particular products, promotion of tourists destinations, encouraging investors to spend money on new projects).

Fig. 1. Managing project of preparing and staging performance during Expo event - planes and determinants

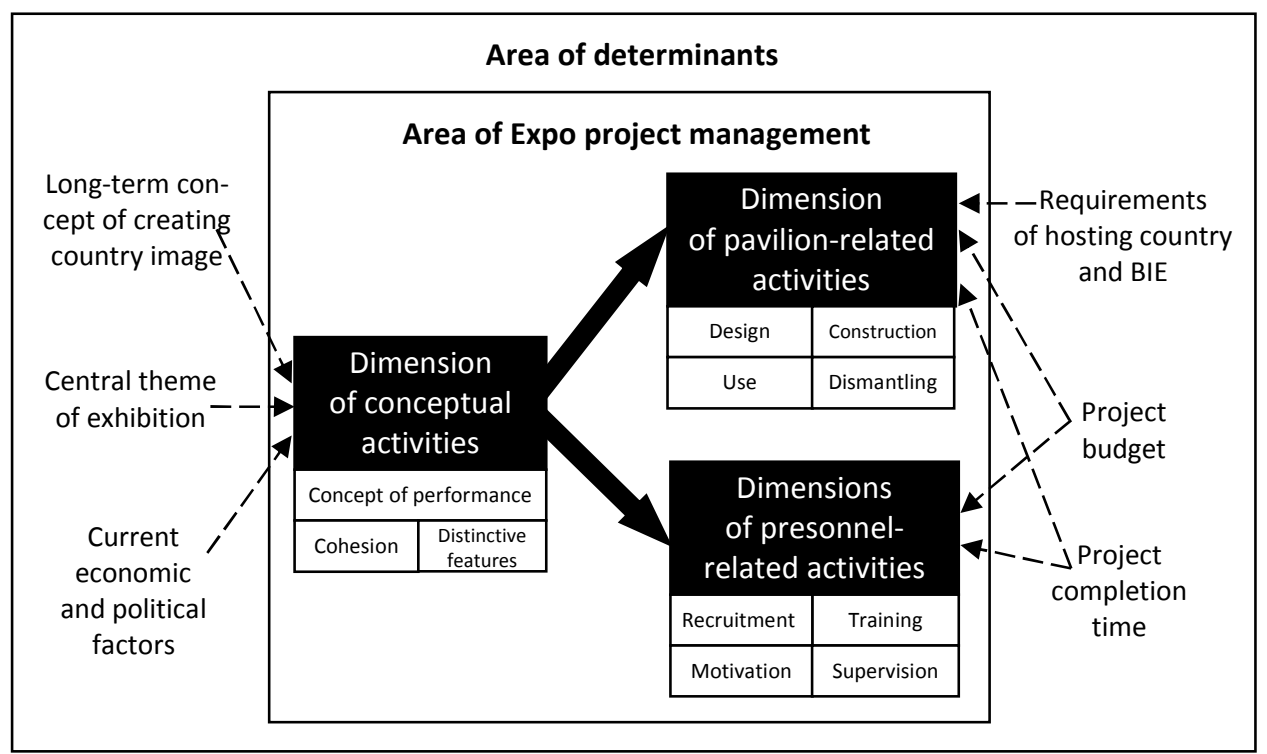

Source: own elaboration.

Considering the dimension of pavilion-related activities, one has to refer to a process comprised of multiple actions, which - in a general sense - can be perceived as the following stages: selecting a project (which is frequently chosen as a result of a contest procedure), erecting the pavilion on Expo premises, using the building during the exhibition, dismantling. Each of the four stages involves management through taking operational

\footnotetext{
${ }^{6}$ E. Björner, P.O. Berg, Strategic creation of experiences at Shanghai World Expo: a practice of communification, "International Journal of Event and Festival Management", 2012/3(1), pp. 30-45.
} 
decisions. Designing a pavilion requires developing a concept of the shape of the building (including its facade), as well as planning individual areas thereof: the entrance zone, the exhibition part, corridors, personnel and utility facilities. When building the pavilion, it is also relevant to carry out numerous actions, including particularly obtaining necessary permits and arranging for a team of construction workers. At this stage, proper logistics is of crucial importance to ensure that material required to construct the pavilion and showpieces is delivered in time. Using the building during the exposition entails mainly repairing possible defects and performing marketing activities inside the building according to a country promotion concept, developed before the event. Except for very few cases, all national pavilions are of a temporary nature and must be dismantled after the exposition finishes. The stage during which the pavilion is being dismantled also requires proper organisation of works and decision-making (e.g. it must be decided what to do with the showpieces exhibited at the Expo).

The very last dimension of taking decisions, also those of an operational nature, involves managing pavilion personnel. In that respect, the following must be highlighted: a recruitment process to select people having appropriate qualities and skills (e.g. who speak the language of a hosting country), training (including, among other things, familiarising staff members with goals of a national performance and informing them about the necessity to perform cohesive promotional actions), motivation and control, constant supervision.

The areas of pavilion and personnel management are determined mainly by a budget available for a performance. It is the amount of financial resources, which has a powerful impact on the way a building presenting a national display looks like, what its size is and what it is equipped with. The budget influences also the number of staff members, as well as diversity of marketing activities. The amount of time that is left before the exhibition opening constitutes also a key determinant. It might be impossible to construct a pavilion containing a complex display and prepare numerous accompanying events - e.g. concerts, economic missions within several months. As a rule, it can be assumed that the time needed to complete a national pavilion does not exceed one year (generally, this is the period of time during which an organiser makes an area available for construction), although in many cases, the completion time is limited to several months or even a couple of weeks ${ }^{7}$. Recruitment and training of personnel should be also planned in advance and requires time. The process of designing, constructing, using and dismantling a pavilion depends also on BIE requirements and legal regulations applicable in a hosting country (e.g. construction law in force).

\section{REVIEW OF PAVILIONS IN THE CONTEXT OF IMPLEMENTING NA- TIONAL BRANDING ASSUMPTIONS}

A pavilion used at a world exposition serves a role of a showpiece, as its appearance decides how many visitors will enter the building. Forming its external shape, arranging the area and setting up a display system, selecting a construction type, materials and colours, deciding what type of lighting and loud speaker system should be used, creating a proper atmosphere - these are instruments employed to present the fundamental message

\footnotetext{
${ }^{7}$ M. Kysiak, Architektura pawilonów wystawowych, Oficyna Wydawnicza Politechniki Warszawskiej, Warszawa 1998, p. 33.
} 
of the national display. The manner how solutions to those problems are found demonstrates the level of intellectual potential and technological capacity of a country which an exhibitor comes from ${ }^{8}$. Throughout the decades, conveying information through the form of pavilions has changed from "record-breaking" engineering achievements to architectural and designer hybrids, supported by state-of-the-art technology. At present, symbolism of exhibition structures is clearer and closer to popular stereotypes or icons with a global range 9 .

Based on the observation of performances given by participants of Expo 2015, it is possible to put forward a classification of national pavilions, which includes a long-term concept (strategy) of country promotion. In that respect, the following three groups can be distinguished:

- pavilions which fit squarely into a current promotional strategy of a country (complying with the assumptions of national branding);

- pavilions which are not connected with a current concept of country promotion, however, which consider existing social, economic or political factors;

- pavilions which are not in line with a long-term concept of country promotion and do not take into account present social, economic or political factors.

An example of a pavilion shown at Expo 2015 which was cohesive with a present concept of creating a national brand was the building used by Slovenia to exhibit its offer (Fig. 2). The pavilion was comprised of five pyramids set on a geometrically diverse surface built from the natural materials (wood and glass). Since 2007, Slovenia has been using the concept of marketing activities named as "I FEEL SLOVENIA", which aims to distinguish the country clearly from other countries. Visual cohesion and consistency in performing promotional activities are supported by the guidelines included in "The brand of Slovenia. Brand book" (this document contains fundamental assumptions of corporate identity) ${ }^{10}$. Referring, through exhibition activity, to the concept of promoting the country image was not only limited to placing the central message of the brand on the facade of the Slovenian pavilion, but entailed also using advertising elements (brochures, leaflets, stickers, gadgets), which were prepared in line with the guidelines set out in the "Brand book".

\footnotetext{
${ }^{8}$ Ibidem, p. 125.

9 W. Świątek, Trzy polskie pawilony na wystawy światowe Expo, „Czasopismo Techniczne. Mechanika” 2012/26, p. 334.

10 „The brand of Slovenia. Brand book" is available on the website: http://www.ukom.gov.si/fileadmin/ ukom.gov.si/pageuploads/dokumenti/arhiv_projektov/IFS/Slovenias_Brand_brand_book.PDF.PDF (access on: 17.09.2015).
} 
Fig. 2. The Slovenian pavilion (own).
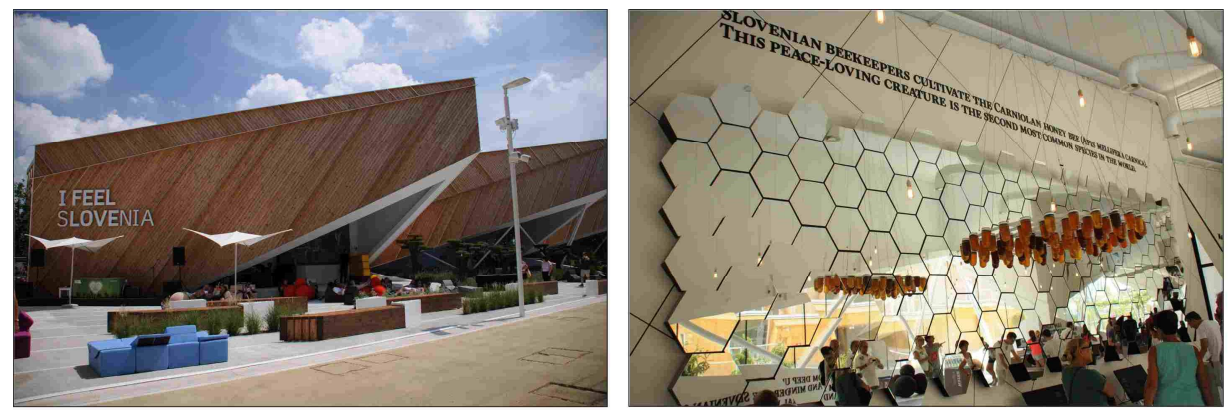

Source: own pictures.

An example of a display, in which greater attention was given to political and economic factors, rather than to the central theme of the Expo, was the pavilion set up by Turkmenistan (Fig. 3) When entering the building, people could see a picture of the Turkmen president, and further, most elements of the display were devoted to rich deposits of natural gas and crude oil. A characteristic feature of the display was glamour and a combination of tradition (folk ornaments, rugs typical of Turkmen yurts) and modernity (a large display in a form of a LED bowl hanging from the ceiling). The roof garden on top of the building presented yurts, traditional carpets and a green area with a café ${ }^{11}$. The whole display was prepared under the slogan "Water is life", even though there were very few references to water inside of the pavilion.

Fig. 3. The Turkmen pavilion
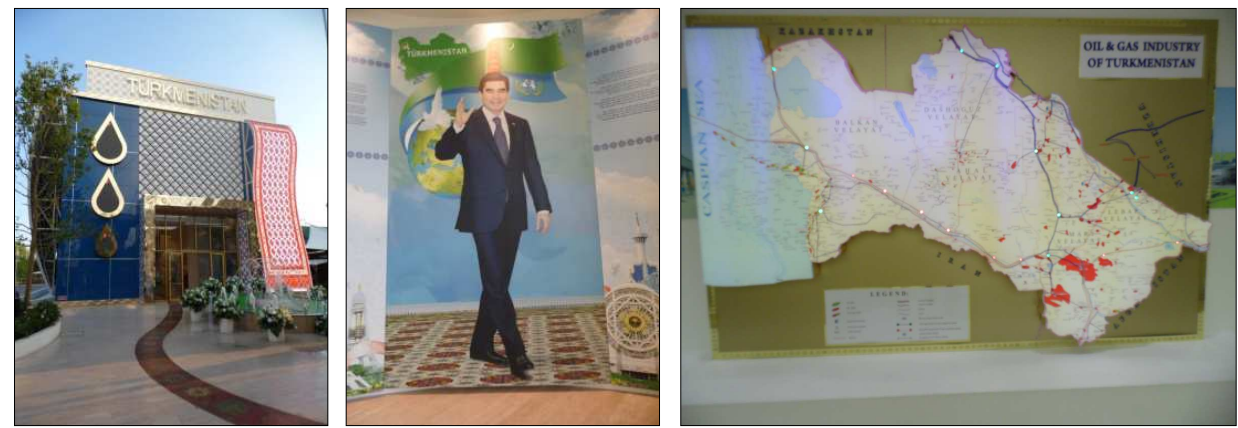

Source: own pictures.

The goal of pavilions classified under the last group, i.e. structures which are not connected with a concept of country promotion and do not take into account current social, economic or political factors, is only to make their presence felt during Expos. Most frequently, such pavilions are buildings with appearance devoid of uniqueness, which form an element of a larger exhibition (complex) group. During Expo 2015, displays staged by some of the exhibitors were located in an isolated area, within a group of identical buildings. So-called "clusters" were created, in which countries were grouped under the following themes: "Rice", "Cocoa and chocolate", "Coffee", "Fruits and legumes", "Spices",

\footnotetext{
${ }^{11}$ Expo Milano 2015. Short guide, Mondadori Electa, 24 Ore Cultura, Milan 2015, p. 30.
} 
"Cereals and tubers“, "Bio-Mediterraneum”, „Islands, sea and food”, “Arid zones”. For example, the "Coffee" cluster comprised countries from different continents: Burundi, El Salvador, Ethiopia, Dominican Republic, Guatemala, Kenya, Rwanda, Uganda, Yemen, Timor-Lest (Fig. 4).

Fig. 4. Pavilions of the "Coffee Cluster"
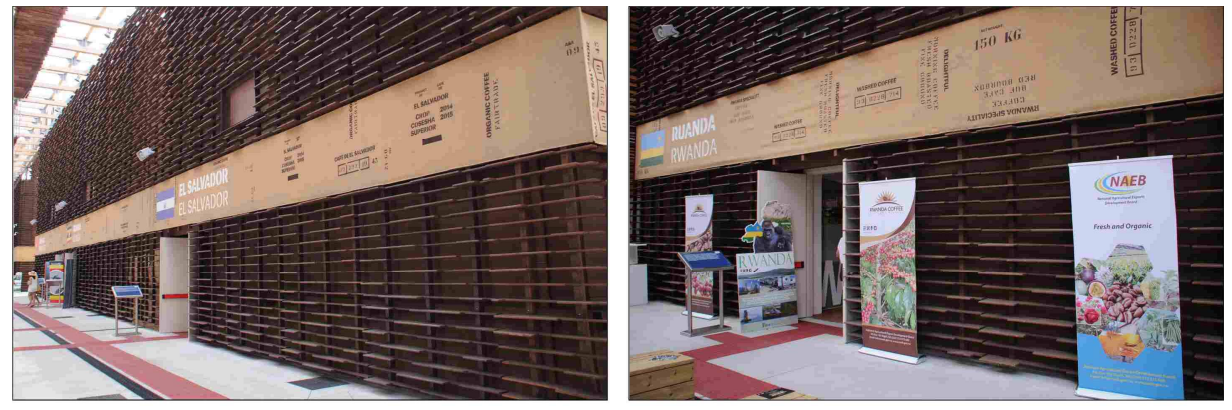

Source: own pictures.

It is worth noting that among the countries exhibiting themselves in the clusters, there were very few cases which - although the external appearance of their buildings was not remarkable - were able to prepare interesting displays inside the pavilions, appealing to visitors and corresponding with the motto of the world exposition. One of such examples included the display staged by Ethiopia (Fig. 5). Apart from presenting a process of gathering and brewing coffee (combined with tasting), a wide range of plants grown in this country was exhibited. The performance was held under the slogan: "Ethiopia: the Root of Coffee and Much More".

Fig. 5. The Ethiopian pavilion
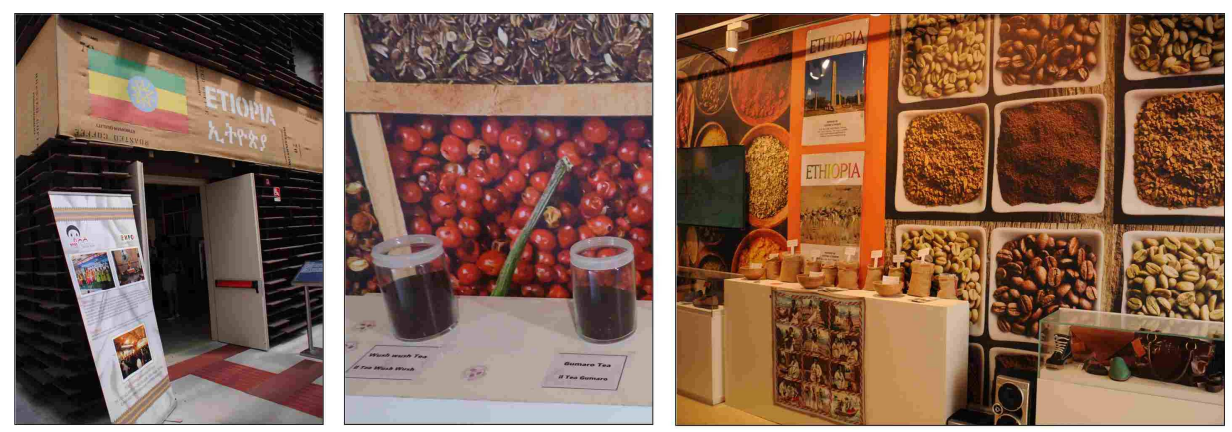

Source: own pictures.

Among the cluster-arranged exhibitors, there were mainly poorer countries, which could not allocate large sums of money to the participation in the Expo. Limited budgets were the reason why they could not erect pavilions based on their own unique designs.

\section{REVIEW OF PAVILIONS IN THE CONTEXT OF REFERRING TO THE CENTRAL EXPO THEME}

It is a common occurrence that there is a main idea lying behind every universal exposition, which is reflected in the central theme. The previous three Expo events were as- 
signed the following slogans: "Nature's Wisdom" (Aichi 2005), "Better City - Better Life" (Shanghai 2010), "Feeding the Planet, Energy for Life" (Milan 2015).

Taking into consideration the level of adjustment of particular countries' performances to a central theme of an exhibition, national pavilions can be categorised as:

- the pavilions which correspond closely with the central exhibition theme;

- the pavilions which correspond loosely with the central exhibition theme;

- the pavilions which do not correspond at all with the central exhibition theme.

An example of the building whose interior, as well as events held therein followed strictly the theme of the exposition, was the German pavilion presented in 2015 - with the title "Fields of Ideas" and the motto "Be(e) Active" (Fig. 6). In this case, the main emphasis was laid on the food of the future. Visitors could see the displays in two ways: by strolling across the freely accessible landscape level, where they were welcomed by the 16 German federal states with their stands, or by visiting the indoor exhibition, here they could find their way from the source of food to food production and right up to consumption in the city ${ }^{12}$. Those who entered the pavilion could interact with displays to access further multimedia information. The climax of the display was the "Be(e)active" digital show, which combined live music with active participation of an audience.

Fig. 6. The German pavilion
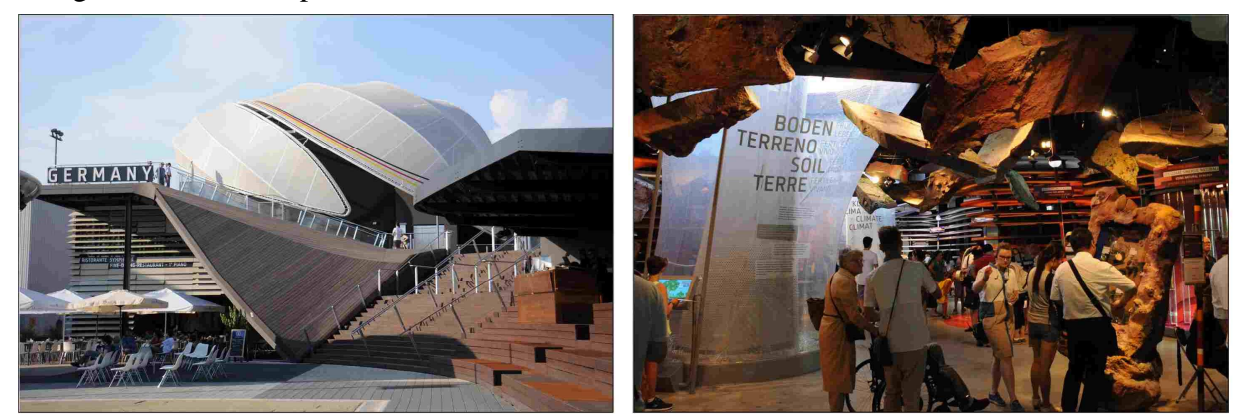

Source: own pictures.

Another pavilion which strongly referred to the Expo theme was the French display, whose message was: "Different Ways of Producing and Providing Food" (Fig. 7). People entering the building had to go through a kind of a labyrinth - the large garden, where plants grown in different parts of the country were presented. The pavilion had a huge cave-like structure and it was made entirely of French wood. The high vaulted roof area mixed typical French products, kitchen utensils, wood and vegetation, with video monitors showing suggestions for "producing more and better"13.

\footnotetext{
${ }^{12}$ Feeding the Planet, Energy for Life. Expo Milano 2015. Official Catalogue, Mondadori Electa, 24 Ore Cultura, Milan 2015, p. 95.

${ }^{13}$ Unmissable: Pavilion attractions, http://www.expo2015.org/en/unmissable--pavilion-attractions, (access on: 21.09.2015).
} 
Fig. 7. The French pavilion
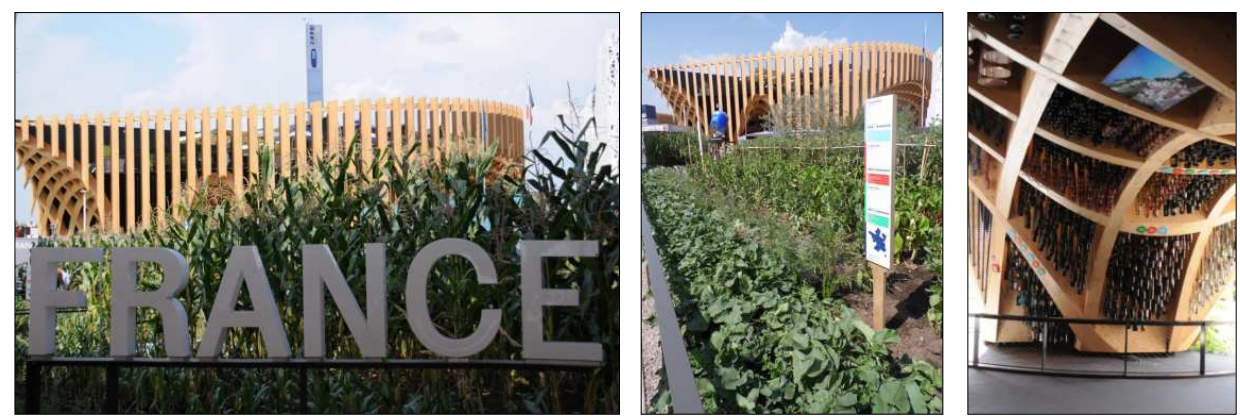

Source: own pictures.

Apart from the pavilions set up by Germany and France, there were also other pavilions that adhered to the theme: "Feeding the Planet, Energy for Life", and these were buildings exhibited by: Argentina, Azerbaijan, Iran, Russia, Spain.

Most of the exhibiting countries prepared performances that reflected the dominant dimension of the exposition, yet only to a moderate extent. The above-mentioned Slovenian pavilion, presented in 2015, exemplified the moderate compliance with the central Expo theme. The following motto was demonstrated during the Slovenia's performance: "I Feel SLOVEnia. Green. Active. Healthy". The exhibitor was present in Milano with five main themes: saltpans, bees, thermal and mineral waters, hiking and cycling, and the measurement of black carbon particles ${ }^{14}$.

Yet another example of referring to the central theme of the exhibition in a moderate manner was the pavilion demonstrated by Slovakia (Fig. 8) The display covered six thematic issues: traditions, nutrition, innovations, experiences, culture and sport. The whole was referred to as: "The World in Your Pocket". Slovakia was shown as "a place for recharging". There was the relaxation area outside the building - consisting of a cube of wooden slats with a waterfall that drove a watermill system - which contained a series of beanbag chairs where smartphones and tablets could be recharged ${ }^{15}$. Inside the pavilion, apart from the demonstration zone, a restaurant was located, where dishes typical of Slovak cuisine were served.

Under the last group of displays, i.e. the ones which did not refer anyhow to the central theme of the exhibition, one has to classify mainly the pavilions of poorest countries. Most frequently, those countries did not have independent pavilions and exhibited themselves in cluster-like arrangements. Their displays were formed predominantly by simple showpieces connected with tourism, and visitors were served by personnel consisting of few people (one or two members). Such an observation was exemplified by the pavilions used by the countries like: Afghanistan, Algeria, Cameroon, Congo, Gambia, Sierra Leone, Uganda, Zimbabwe. Sometimes, a food zone was used as the main part of the display, where visitors could taste regional dishes and drinks, which was the case, for example with Cuba and Bangladesh.

\footnotetext{
${ }^{14}$ Feeding the Planet, Energy for Life. Expo Milano 2015. Official Catalogue, Mondadori Electa, 24 Ore Cultura, Milan 2015, p. 152.

${ }^{15}$ Unmissable: Pavilion attractions, http://www.expo2015.org/en/unmissable--pavilion-attractions (access on: 21.09.2015).
} 
Fig. 8. The Slovak pavilion
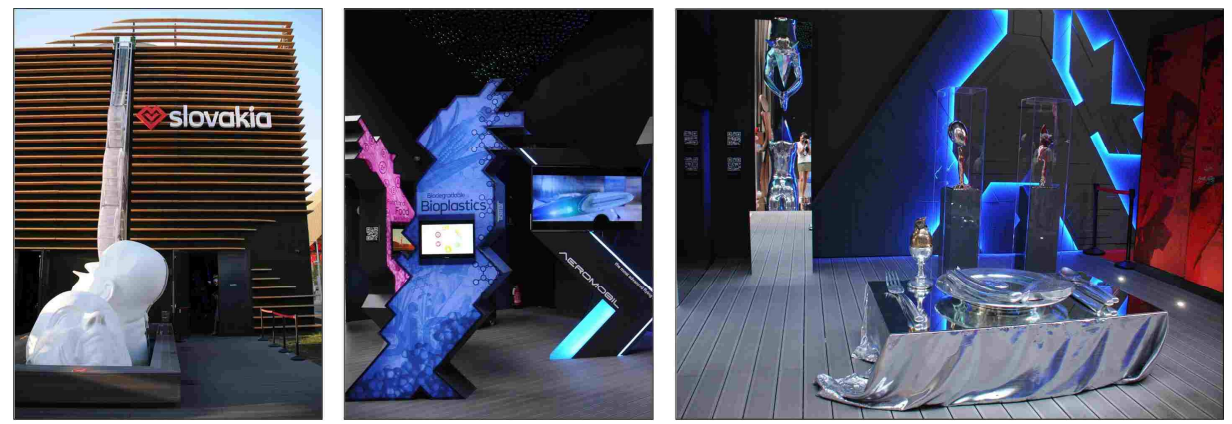

Source: own pictures.

The last group covers also displays which were more similar to gift stalls, rather than to exhibition pavilions. The main part of such displays included handicrafts (e.g. jewellery, sculptures, paintings), clothes (regional costumes, headgear) and foodstuffs (like honey, spices) characteristic of a specific country and offered for sale to people who appeared at the Expo. The pavilions where Laos, Yemen, Sudan, India (Basmati Pavilion) held their exhibitions, could be good examples of the above observation.

In addition, it must be mentioned that Expo 2015 comprised not only buildings with national displays, but also several pavilions used by: international organisations (e.g. the European Union), non-profit organisations (such as Save the Children International), corporations (e.g. New Holland Agriculture). Moreover, the exhibition included thematic areas devoted to important matters - e.g. the Pavilion Zero, where a relation between the Earth and food and nature was demonstrated.

\section{POLISH PAVILION DURING EXPO 2015}

The Polish pavilion, covering the area of 2,369 sq. m., was the fourth largest pavilion out of all the countries participating in Expo 2015 (Fig. 9). Visitors could begin sightseeing on the first floor where they had to walk through a "magic garden", covered with plants growing on Polish meadows and in orchards, including apple trees. There was no roof above the garden, and its walls were covered with mirrors, which created an illusion of vast space. From the garden, visitors entered the inside of the pavilion. The demonstration zone consisted of a place where showpieces were shown and films were played, both of which exhibited Polish landscapes, state-of-the-art agriculture and rapid economic growth of Poland. Further, there were a section devoted to the country's regions and a place intended for special events, where piano concerts of Frédéric Chopin's music were performed. The pavilion featured a shop (where visitors could buy traditional products among other things, jam, honey, alcohol) and a restaurant (serving dishes characteristic of Polish cuisine - such as żurek (a sour soup), pierogi (dumplings), placki ziemniaczane (potato pancakes). 
Fig. 9. The Polish pavilion
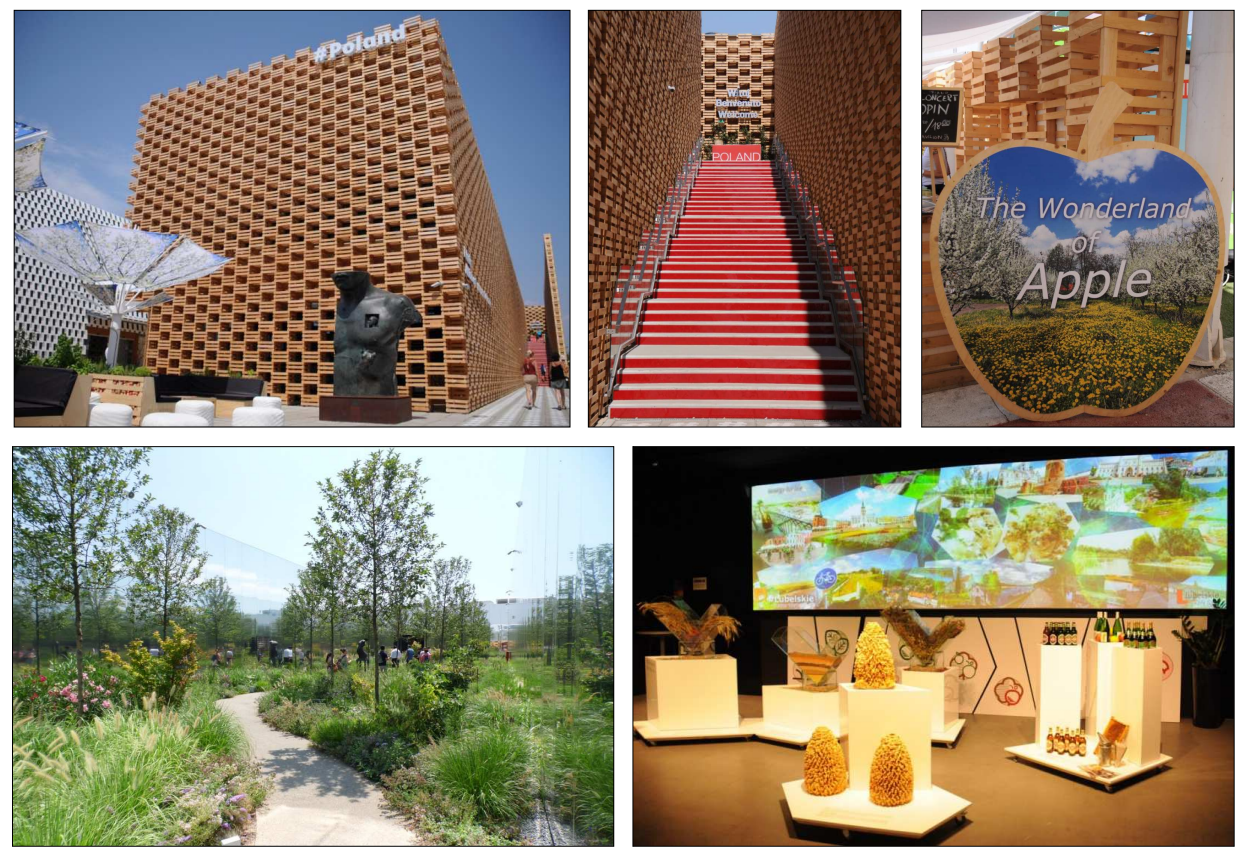

Source: own pictures.

The dominant motif used in the Polish pavilion was a wooden apple box, used in shipment as packaging for those fruits. The facade of the building was constructed in such a way that it resembled hundreds of wooden boxes piled one on another. Furthermore, the whole pavilion, because it was in a form of a cube, when seen from a certain distance could be perceived as a large-scale box. Additionally, the motif of apple boxes was utilised at the stalls set up in front of the pavilion, where Polish foodstuffs and beer were sold. The name of the country placed on the facade of the building was preceded by a "\#" sign, which was supposed to trigger an association with an apple box. There was also an open space where seats for visitors were located under umbrellas illustrating growing apple trees, and those who decided to have a rest in that area were given the opportunity to taste apple juice. People entering the display area were welcomed by a display board showing a picture of an orchard and a slogan: "The Wonderland of Apple".

The main motif of the pavilion centred thus around agriculture, and in particular, around the production of apples. Such a profile of the display should be correlated with the embargo imposed by Russia on Polish foodstuffs, which was symbolised by apples in the years 2014-2015. Therefore, the Polish display took into consideration current economic and political factors. Moreover, due to the fact that great emphasis was laid on the agricultural and food industry, the display reflected, to a considerable extent, a part of the theme of Expo 2015 ("Feeding the Planet").

The Polish display was an example of a pavilion not directly connected with a longterm country promotion concept, as it was based on new symbolism - that had not been 
seen in any promotional activities before. The motif of apple boxes was prepared only for the purpose of the exhibition activity in Milan.

\section{CONCLUSIONS}

Based on the visits made to the national pavilions exhibited at Expo 2015, a classification of national displays has been put forward. This has demonstrated that performances can be perceived in respect of different dimensions which allow for grouping them under various categories, considering the cohesion between displays and assumptions of a country promotion concept, as well as with regard to the aspect of adhering to a central theme of an exhibition. Pictures of selected pavilions have been shown together with descriptions to exemplify the above. Each category can be illustrated by further examples, however, owing to the word limit of this paper, it is not possible to discuss more displays. Taking into account the effectiveness of pursuing marketing goals, it is the most desirable when an exhibition project is managed in such a way that a specific country can be displayed attractively (focusing, among other things, on its natural values, scientific and cultural achievements, economic accomplishments), complying with a concept of national branding and adhering to a central theme of an exposition.

While walking around the grounds of Expo 2015, absence of many countries could be noticed. Not only those less affluent, but also rich ones - such as: Australia, Canada, Denmark, Finland, Norway, Sweden. The reason given for the absence was high participation costs. It is noteworthy that some of these countries exhibited themselves on a grand scale five years ago during Expo in Shanghai. For instance, in 2010, the Danish pavilion generated intense media interest, as the original statue of the Little Mermaid was transported from Copenhagen and put inside the exhibition building. A distinctive feature of the Swedish pavilion, on the other hand, was an environment-friendly structure (it was built of energy-efficient steel that made it possible to use the heat of the Sun to warm up the inside of the building). And as for the Australia's display at the Shanghai exhibition, the country erected one of the largest pavilions - covering an area of 4,800 sq. m. Originally, Poland was not going to take part in Expo 2015, yet finally, the Polish government decided to prepare the display. The cost of Poland's participation in the Milan event is estimated at approx. PLN 57 million, however, the display was part-financed (three fourth of the sum) by the European Union with the European Regional Development Fund.

Such a situation should provoke us into posing a question whether - considering the high costs of preparing and running pavilions and taking into account universal access to the Internet - participation in world expositions still makes any sense. Yet that is a difficult question to be unequivocally answered. The Internet creates opportunity for presenting oneself on the Web, however, it triggers only sight and hearing, whereas the other senses of recipients of marketing activities are not activated. Participating in an Expo, on the other hand, enables visitors to "feel" exhibitors' offers with all the senses. This happens in a unique atmosphere created by face-to-face contact with representatives of many countries and through participation in multiple remarkable events that accompany the main exhibition. The answer for the question related to the reason behind participating in Expos will be given by the next exposition, which will be held in 2020 in Dubai. This event will demonstrate how many countries in the 21 st century, nearly 170 years after the first universal exposition, are still capable of achieving the situation when exhibit marketing balances out costs of participation. 


\section{BIBLIOGRAPHY}

[1] Björner E., Berg P.O., Strategic creation of experiences at Shanghai World Expo: a practice of communification, "International Journal of Event and Festival Management", 2012/3(1).

[2] Chen N., Branding national images: The 2008 Beijing Summer Olympics, 2010 Shanghai World Expo, and 2010 Guangzhou Asian Games, "Public Relations Review", 2012/38(5).

[3] De Carlo M., Canali S., Pritchard A., Morgan N., Moving Milan towards Expo 2015: designing culture into a city brand, "Journal of Place Management and Development", 2009/2(1).

[4] Deng C.Q., Li M., A model of event-destination image transfer, "Journal of Travel Research", 2014/53(1).

[5] Deng C.Q., Li M., Shen H., Developing a measurement scale for event image, "Journal of Hospitality \& Tourism Research", 2015/39(2).

[6] Expo Milano 2015. Short guide, Mondadori Electa, 24 Ore Cultura, Milan 2015.

[7] Feeding the Planet, Energy for Life. Expo Milano 2015. Official Catalogue, Mondadori Electa, 24 Ore Cultura, Milan 2015.

[8] Kysiak M., Architektura pawilonów wystawowych, Oficyna Wydawnicza Politechniki Warszawskiej, Warszawa 1998.

[9] Lee Ch.-K., Kang S.K., Lee Y.-K., Segmentation of Mega Event Motivation: The Case of Expo 2010 Shanghai China, "Asia Pacific Journal of Tourism Research”, 2013/18(6).

[10] Świątek W., Trzy polskie pawilony na wystawy światowe Expo, „Czasopismo Techniczne. Mechanika" 2012/26.

[11] Unmissable: Pavilion attractions, http://www.expo2015.org/en/unmissable--pavilionattractions (access on: 21.09.2015).

[12] Xue K., Chen X., Yu M., Can the World Expo change a city's image through foreign media reports?, "Public Relations Review", 2012/38(5).

[13] Yu L., Wang Ch., Seo J., Mega event and destination brand: 2010 Shanghai Expo, "International Journal of Event and Festival Management”, 2012/3(1).

\section{ODZWIERCIEDLENIE STRATEGII PROMOCYJNEJ W ZRÓŻNICOWANIU PAWILONÓW NARODOWYCH PODCZAS EXPO 2015}

Celem artykułu jest sklasyfikowanie pawilonów przygotowanych na wystawy światowe. Przeprowadzając klasyfikację uwzględniono z jednej strony spójność poszczególnych wystąpień narodowych z założeniami brandingu narodowego, z drugiej zaś - dopasowanie tych wystąpień do przewodniej idei Expo. W pierwszej części artykułu przedstawiono kluczowe płaszczyzny i determinanty zarządzanie projektem przygotowania oraz realizacji wystąpienia podczas wystawy światowej. Z kolei w drugiej części publikacji, na podstawie obserwacji przeprowadzonej przez autora podczas Expo 2015, zaproponowano podział pawilonów narodowych. W kontekście kreowania wizerunku kraju wyodrębniono: pawilony ściśle wpisujące się w aktualną strategię promocyjną kraju (spełniające założenia brandingu narodowego); pawilony niezwiązane z obecną koncepcję promowania kraju, wpisujące się jednak w aktualne uwarunkowania społeczne, gospodarcze lub polityczne; pawilony oderwane od długofalowej koncepcji promowania kraju i niewpisujące się w aktualne uwarunkowania społeczne, gospodarcze lub polityczne. Ponadto, biorąc pod uwagę dopasowanie wystąpień poszczególnych krajów do wiodącego tematu wydarzenia, wyodrębniono: pawilony ściśle nawiązujące do idei przewodniej wystawy; pawilony luźno nawiązujące do idei przewodniej wystawy; pawilony, w których wystąpił brak odwołania do idei przewodniej wystawy. W ramach egzemplifikacji przywołano ekspozycje: Etiopii, Francji, Niemiec, Słowacji, Słowenii i Turkmenistanu. Szczególną uwagę poświecono polskiemu pawilonowi. Autor zaprezentował także krytyczne spojrzenie na zasadność uczestnictwa państw w wystawach świa- 
towych w XXI wieku - w kontekście wysokich kosztów przygotowania ekspozycji, jak również powszechnego dostępu do internetu.

Słowa kluczowe: wystawy światowe, zarządzanie wystąpieniem targowym, architektura targowa, wizerunek kraju.

\section{DOI: 10.7862/rz.2015.mmr.54}

Tekst złożono w redakcji: październik 2015

Przyjęto do druku: styczeń 2016 